\title{
Effects of Seasonal Changes in Internal Air Quality and Comparing the Efficacy of Different Disinfectants Used in Laboratory of Benghazi Center of Infectious Diseases and Immunity
}

\author{
Muna Mohammed Buzayan ${ }^{1 *}$ and Bouthina K. Greiw ${ }^{2}$ \\ ${ }^{1}$ National Center for Diseases Control, Libya \\ ${ }^{2}$ Chair of scientific committee of Reproductive Health of National Centre for Diseases \\ Control, (NCDC) Libya \\ *Corresponding author
}

\section{A B S T R A C T}

\begin{tabular}{|l|}
\hline K e y w o r d s \\
$\begin{array}{l}\text { Bacteria, Indoor air } \\
\text { quality, Gram positive } \\
\text { bacteria, Gram negative } \\
\text { bacteria, Medical } \\
\text { laboratory, Different } \\
\text { disinfectants }\end{array}$ \\
\hline Article Info \\
\hline $\begin{array}{l}\text { Accepted: } \\
\text { 02 May 2018 } \\
\text { Available Online: } \\
\text { 10 June 2018 }\end{array}$ \\
\hline
\end{tabular}

A cross sectional descriptive study conducted in Benghazi centre of infectious diseases and immunity (BCIDI) during winter and spring from December 2013 to April 2014. Samples were collected by using the settled plate techniques for the enumeration of bacterial isolates. The air specimens were collected three times; in the morning between the hours of 9 am and $10 \mathrm{am}$, in the afternoon between 2 noon and $3 \mathrm{pm}$ and in the evening between the hours of $7 \mathrm{pm}$ and $8 \mathrm{pm}$ for two seasons. Used of different disinfectants in routine cleaning surfaces on isolated bacteria. From the total microbial population of different sites, the highest bacterial population was recorded in the morning as compared to the afternoon and evening. 18 genera of bacteria were isolated, gram positive bacteria accounting $(87 \%)$ was significantly higher than of gram negative bacteria (13\%). Gram negative bacteria were found in spring season only. Strains representative of Staphylococcus sp. were the most prevalent $(30.79 \%)$ accounting of the isolated bacteria. The susceptibility pattern of all isolates revealed sensitivity to all tested antibiotics. Different susceptibility of gram positive and negative bacteria towards different concentrations of used disinfectants.

\section{Introduction}

Indoor air quality (IAQ) is a term which refers to the air quality within and around buildings especially as it relates to the health and comfort of its occupants (Tambeker et al., 2007). The IAQ in health care facilities plays an important role in the prevention of infection in hospitals to protect both hospital staff and patients (Leung and Chain, 2006). Prevention and control of microbial spread depends on the quality of hospital routine cleaning services, as well as the type of disinfectants used to diminish risks of cross infections during healthcare assistance (Kramer et al., 2006).

The importance of estimation of the quantity and types of airborne microorganisms is to use these values as an index for the cleanliness of the environment and decide source of hospitalacquired infections (Spendlove and Fannin, 1983). In indoor environments, the main source for microbes is usually the outdoor air 
(Codina et al., 2008; Shelton et al., 2002). Outdoor microbial concentrations vary according to geographical location, the season and time of day. These variations are also reflected in indoor air (Bartlett et al., 2004; Codina et al., 2008) also local climate, weather patterns etc. that might lead to enormous differences of airborne bacteria in different regions (Lee and Jo, 2006; Codina et al., 2008) .In addition to outdoor sources, indoor microbes can originate from indoor sources such as the occupants themselves and their activities (Lehtonen et al., 1993). Other factors influencing the microbial population include building maintenance, cleanliness, indoor temperature and relative humidity, type of furniture, and carpeting (Mandal and Brandl, 2011) .

The process of disinfection may be affected by many variables like contact period, $\mathrm{pH}$ and concentration of the disinfectant, and hardness of water used for dilution. Therefore, the disinfectant ought to be tested in the field for the specified application to ensure its effectiveness (Singh et al., 2012).

This study aimed to gain knowledge regarding the air quality in the medical laboratory in BCIDI and to also know effect potency of disinfectants commonly used in laboratory routine cleaning services on isolated Bacteria.

\section{Materials and Methods}

Cross sectional study was conducted to measure indoor air microbial quality of medical laboratory (rooms, corridors, and hall) of BCIDI from December 2013 to April 2014. The study sites were divided into three units which include all the departments of laboratory.

The Samples were collected in spring and winter seasons. About 57 samples each season from indoor air medical laboratory collected from three times (morning, afternoon and evening) by using purposive sampling technique by Settle Plate Method (Passive Air Sampling following 1/1/1 Schedule) on blood agar (BA) for bacteria culture (Kelkar and Kulkarni, 2011; Reijula and Sundman-Digert, 2004). Each plate was leaving open to the air for a 30 minutes (Kelkar and Kulkarni, 2011), one meter to one and half meter above the floor and a meter from the wall (Ekhaise and Ogboghodo, 2011). The air samples collected (at 9-10 mornings, 2-3 afternoon and 7-8 evening) within a given day. The blood agars settled plate then incubated at $37^{\circ} \mathrm{C}$ for $24-$ 48 hours (Ekhaise et al., 2010).

The number of microorganisms expressed as $\mathrm{CFU} / \mathrm{m}^{3}$ was estimated according to the equation (Bhatia and Vishwakarma, 2010; Stryjakowska Sekulska, 2007):

$\mathrm{CFU} / \mathrm{m}^{3}=\mathrm{a} \cdot 10000 / \mathrm{p} \cdot \mathrm{t} \cdot 0.2$

Where:

$\mathrm{a}$ - the number of colonies on the Petri plate

$\mathrm{p}$ - The surface of the Petri plate

$\mathrm{t}$ - The time of Petri plate exposure

The Antibiotic susceptibility test was done on Mueller-Hinton agar (MHA) (BD) by using Kirby-Bauer disk diffusion method according to the British society for antimicrobial chemotherapy (BSAC) guidelines (BSAC, 2011). Staphylococcus aureus ATCC25923 and Escherichia coli ATCC 25922 strains were used as control organisms. The

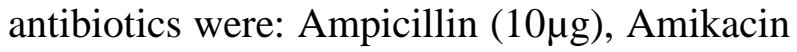
$(30 \mu \mathrm{g})$, Amoxycillin-clavulanic acid $(30 \mu \mathrm{g})$, Ceftriaxone $(30 \mu \mathrm{g})$, Ceftazidime $(30 \mu \mathrm{g})$, Cefotaxime $(30 \mu \mathrm{g})$, Clindamycin $(2 \mu \mathrm{g})$, Erythromycin $(15 \mu \mathrm{g})$, Gentamicin $(10 \mu \mathrm{g})$, Imipenem (10 $\mu \mathrm{g})$, Aztreonam (30 $\mu \mathrm{g})$, Cefoxitin (30 $\mu \mathrm{g}), \quad$ Trimethoprimsulfamethoxazole $(25 \mu \mathrm{g})$, ciprofloxacin (5 $\mu \mathrm{g})$, Tetracycline $(30 \mu \mathrm{g})$, Vancomycin $(5 \mu \mathrm{g})$ 
(Oxoid Ltd., Cambridge, UK). The results were recorded as susceptible, intermediate, and resistant according to the British society for antimicrobial chemotherapy (BSAC, 2011) recommendations.

Isolation of Bacteria was performed by sub streaked on the same medium to obtain pure colonies. Bacterial colonies were identified by using gram stain, biochemical examination, API 20E (bioMerieux, France) and/or Phoenix ${ }^{\mathrm{TM}}$ Automated Microbiology System (Becton Dickinson, USA) (BD) of the isolates.

\section{Selection of disinfectants}

The disinfectants were used in this the study included Ethanol 75\% (Holland), sodium hypochlorite (Clorox, Egypt), sodium hypochlorite (bleach, Benghazi), BIGUANID FLÄCHE N (1.0\%) composition contains Quaternary ammonium compounds, benzylC12-16 alkyldimethyl and Chlorides (German) and WipoiKarbolwangi classic pine (bottle $800 \mathrm{ml}$, Indonesia) and were selected on frequency of use in the medical Laboratory.

\section{Disinfectants Susceptibility Assay on Isolated Bacteria}

Detecting the effect of disinfectants was done by: preparing the isolated bacteria solution in sterile Distilled water having opacity of Mc Farlands 0.5 standard and labelled as 1 .

Dilute 0.5 Mc Farlands solution to 1:2, 1:4, $1: 8,1: 16$, and 1:32 in sterile Distilled water by using double dilution technique. These concentrations are labelled as 2, 3, 4, 5, 6 respectively.

Same way, we put the disinfectant solutions in the above concentrations of 1:1, 1:2, 1:4, 1:8, $1: 16,1 \mathrm{ml}$ each in sterile screw cap test tube. These different disinfectant concentrations were labelled as $\mathrm{A}, \mathrm{B}, \mathrm{C}, \mathrm{D} \mathrm{E}$, and $\mathrm{F}$ respectively. The diluent for the disinfectants was peptone water. Five sets of each concentration of both types of solutions were prepared.

Each set was inoculated with $100 \mu$ of organism of each concentration. A to $\mathrm{F}$ into 1 to 6 .

After inoculation, the test tubes were kept at room temperature for the defined contact time required for the disinfection (5 minutes). After contact period is over, inoculums from each test tube taken and cultured into nutrient agar plate to see the viability of the organism. The plates are incubated for overnight incubation at $37^{\circ} \mathrm{C}$. the results were calculated from the growth on the plates, after 18 to 24 hour the results were noted.

1:32 concentration of microorganism and 1:1 concentration of disinfectant were taken as positive and negative control respectively. Disinfectant having good antibacterial activity tends to remain near to base line highest activity line (Tada et al., 2011).

\section{Results and Discussion}

Air samples from each sampled medical lab rooms studied were taken and used for enumeration and isolation of airborne bacteria on BA plates. Table 1 and 2 shows bacteria isolated from the medical lab rooms studied in two seasons. With regard to the bacterial groups, 18 genera and 23 species of culture able airborne bacteria were determined from different sites (Table 1 and 2).

Microorganism concentrations in the air vary not only during a season but also throughout the day. Average number of bacteria present in indoor air of different rooms in morning, afternoon and evening during spring and winter of study were compared in tables 1 and 2 . 
Afternoons and evenings bacterial air contamination were always lower than the mornings during the two seasons. During spring season evening bacterial air concentrations were higher than the afternoon .

The bacterial counts $\left(\mathrm{CFU} / \mathrm{m}^{3}\right.$ air $)$ on BA ranged from $0.26 \mathrm{CFU} / \mathrm{m}^{3}$ air to 37.45 $\mathrm{CFU} / \mathrm{m}^{3}$ of the winter season. The bacterial $\mathrm{CFU} / \mathrm{m}^{3}$ air in the spring season was significantly higher than that in the winter season (the range from $0.26 \mathrm{CFU} / \mathrm{m}^{3}$ air to 46.35 CFU/m $\mathrm{m}^{3}$ air) (Table 1 and 2).

Analysis of bacterial flora composition in investigated medical laboratory rooms in the two seasons revealed dominating contributions of bacteria from the following genera: Staphylococcus spp. $(\mathrm{n}=279)$, Micrococcus luteus $(\mathrm{n}=239)$, and Kocuria rosea $(\mathrm{n}=142)$.

Some Gram negative bacteria from the following genera: Acinetobacter lwoffii / haemolyticus $(\mathrm{n}=72)$, Moraxella species $(\mathrm{n}=33)$ and Providencia rettgeri $(\mathrm{n}=13)$ were isolated from indoor air (Table 1 and 2).

The types of microorganisms isolated from the air of the different locations are shown in tables 1 and 2. Gram positive bacteria in spring season were more than gram positive bacteria in winter season, also gram-negative bacteria found in spring season only. The largest quantity of isolated bacteria in the two seasons was Micrococcus luteus $(\mathrm{n}=239$, $26.37 \%)$.

Regarding spring season, the most abundant bacteria were Staphylococci capitis sub capitis (46.35 $\mathrm{CFU} / \mathrm{m}^{3}$ ), followed by Micrococcus luteus $\quad\left(25.14 \quad \mathrm{CFU} / \mathrm{m}^{3}\right), \quad$ Acinetobacter lwoffii/haemolyticus $\left(18.86 \mathrm{CFU} / \mathrm{m}^{3}\right)$ and $S$. homonii $\left(16.76 \mathrm{CFU} / \mathrm{m}^{3}\right)$ were the most abundant. In winter season, the most abundant bacteria were Micrococcus luteus (37.45 $\mathrm{CFU} / \mathrm{m}^{3}$ ), followed by Kocuria rosea $(36.66$ $\left.\mathrm{CFU} / \mathrm{m}^{3}\right)$. The susceptibility patterns of all isolates revealed sensitivity to all the antibiotics tested.

The current study showed different levels of the susceptibility patterns against the isolated bacteria to disinfectant solutions tested, which are routinely used, in medical lab. Sodium hypochlorite was the compound which showed the highest effect on all tested bacteria. Gram positive bacteria were high (strong) susceptible against all disinfectants that used in this study, no growth showed in all concentrations of disinfectants. While gram negative bacteria were high (strong) susceptible to sodium hypochlorite and less susceptible to BIGUANID FLÄCHE N and Wipol disinfectants while Ethanol showed non- activity on gram negative bacteria (Table 3).

The study of airborne microorganisms in indoor environments is important to understand the dissemination of airborne microbes particularly the pathogenic ones (Jaffal et al., 1997), furthermore the number and type of airborne microorganisms can be used to determine the degree of cleanliness. Present surveys found IAQ play an important role and has a strong and direct correlation with work efficiency output. Earlier scientific studies indicate that $15 \%$ of work performance can be increased when the building occupants are comfortable with their environment (Mahbob et al., 2011). Regular surveillance, cleaning and restriction of movement relative might be among the strict measures necessary to reduce or totally eliminate the microbial load of indoor air of this lab rooms.

The microbial isolates characterized and identified included 18 genera of bacteria. The number of bacteria in our research, it should be stated that the degree of microbial contamination in a tested area was in permitted levels from $0.26 \mathrm{CFU} / \mathrm{m}^{3}$ to 46.35 $\mathrm{CFU} / \mathrm{m}^{3}$. 
Table.1 Enumeration of bacteria $\left(\mathrm{CFU} / \mathrm{m}^{3}\right.$ air $)$ of winter season according to the time of sampling

\begin{tabular}{|l|}
\multicolumn{1}{|c|}{ Bacteria } \\
\hline Gram Positive Bacteria \\
\hline Arcanobacterium haemolyticum \\
\hline Bacillus cereus \\
\hline Bacillus thuringiensis \\
\hline Micrococcus luteus \\
\hline Macrococcus caseolyticus \\
\hline Globicatella sanguinis \\
\hline Leifsonia aquatica \\
\hline Kocuria rosea \\
\hline Staphylococcus haemolyticus \\
\hline Staphylococcus kloosii \\
\hline Paenibacillus alvei \\
\hline Pediococcus pentosaceus \\
\hline Pantoea agglomerans \\
\hline Total \\
\hline CFU/m
\end{tabular}

\begin{tabular}{|c|c|c|c|c|}
\hline \multicolumn{5}{|c|}{ Winter } \\
\hline Morning $(9-10 \mathrm{am})$ & Afternoon $(2-3 \mathrm{pm})$ & Evening $(7-8 \mathrm{pm})$ & Total & CFU/m \\
\hline 0 & 2 & 0 & 2 & 0.52 \\
\hline 4 & 4 & 1 & 9 & 2.36 \\
\hline 9 & 4 & 11 & 24 & 6.29 \\
\hline 86 & 20 & 37 & 143 & 37.45 \\
\hline 1 & 0 & 0 & 1 & 0.26 \\
\hline 0 & 0 & 0 & 0 & 0 \\
\hline 1 & 7 & 1 & 9 & 1.83 \\
\hline 89 & 36 & 15 & 140 & 36.66 \\
\hline 25 & 0 & 5 & 30 & 7.86 \\
\hline 0 & 2 & 0 & 2 & 0.52 \\
\hline 3 & 0 & 0 & 3 & 0.79 \\
\hline 6 & 0 & 0 & 6 & 1.57 \\
\hline 1 & 0 & 0 & 1 & 0.26 \\
\hline 225 & 75 & 70 & 370 & 96.89 \\
\hline 58.92 & 19.64 & 18.33 & 96.89 & \\
\hline & & & & \\
\hline
\end{tabular}

Table.2 Enumeration of bacteria $\left(\mathrm{CFU} / \mathrm{m}^{3}\right.$ air) of spring season according to the time of sampling

\begin{tabular}{|c|c|c|c|c|c|}
\hline \multirow[t]{2}{*}{ Bacteria } & \multicolumn{5}{|c|}{ Spring } \\
\hline & Morning (9 - $10 \mathrm{am})$ & Afternoon $(2-3 \mathrm{pm})$ & Evening $(7-8 \mathrm{pm})$ & Total & $\mathrm{CFU} / \mathrm{m}^{3}$ \\
\hline \multicolumn{6}{|l|}{ Gram Positive Bacteria } \\
\hline Aerococcus viridans & 23 & 1 & 0 & 24 & 6.29 \\
\hline Bacillus cereus & 0 & 1 & 0 & 1 & 0.26 \\
\hline Bacilliusmegataterium & 0 & 1 & 0 & 1 & 0.26 \\
\hline Bacillius coagulans & 0 & 1 & 0 & 1 & 0.26 \\
\hline Dermacoccus nishinomiyaensis & 4 & 0 & 0 & 4 & 1.05 \\
\hline Enterococcus sp. & 0 & 1 & 7 & 8 & 2.09 \\
\hline Micrococcus luteus & 45 & 11 & 40 & 96 & 25.14 \\
\hline Macrococcus caseolyticus & 2 & 0 & 0 & 2 & 0.52 \\
\hline Globicatella sanguinis & 11 & 0 & 0 & 11 & 2.88 \\
\hline Leifsonia aquatica & 0 & 6 & 0 & 6 & 1.57 \\
\hline Kocuria rosea & 2 & 0 & 0 & 2 & 0.52 \\
\hline Kytococcus sedentarius & 6 & 0 & 0 & 6 & 1.57 \\
\hline $\begin{array}{l}\text { Staphylococcus capitis sub } \\
\text { capitis }\end{array}$ & 89 & 0 & 88 & 177 & 46.35 \\
\hline Staphylococcus aureus & 0 & 0 & 1 & 1 & 0.26 \\
\hline Staphylococcus kloosii & 4 & 0 & 0 & 4 & 1.05 \\
\hline Staphylococcus hominis & 43 & 4 & 17 & 64 & 16.76 \\
\hline Staphylococcus lentus & 1 & 0 & 0 & 1 & 0.26 \\
\hline Paenibacillus alvei & 0 & 1 & 0 & 1 & 0.26 \\
\hline Pediococcus pentosaceus & 8 & 0 & 0 & 8 & 2.09 \\
\hline \multicolumn{6}{|l|}{ Gram Negative Bacteria } \\
\hline $\begin{array}{l}\text { Acinetobacter } \\
\text { lwoffii//haemolticus }\end{array}$ & 0 & 0 & 72 & 72 & 18.86 \\
\hline Moraxella species & 0 & 33 & 0 & 33 & 8.64 \\
\hline Providencia rettgeri & 0 & 13 & 0 & 13 & 3.40 \\
\hline Total & 238 & 73 & 225 & 536 & 140.37 \\
\hline $\mathrm{CFU} / \mathrm{m}^{3}$ & 62.33 & 19.12 & 58.92 & 140.37 & \\
\hline
\end{tabular}


Table.3 Susceptibility of isolated bacteria from disinfectants

\begin{tabular}{|l|l|l|l|l|l|}
\hline \multicolumn{1}{|c|}{ Type of bacteria } & Ethanol & $\begin{array}{c}\text { Clorox } \\
\text { (sodium } \\
\text { hypochlorite) }\end{array}$ & $\begin{array}{c}\text { Biguanid } \\
\text { Fläche N } \\
\text { (Quaternary } \\
\text { ammonium } \\
\text { compounds })\end{array}$ & $\begin{array}{c}\text { Bleach } \\
\text { (sodium } \\
\text { hypochlorite) }\end{array}$ & Wipol \\
\hline Staph.aureus & High & High & High & High & High \\
\hline Bacillus cereus & High & High & High & High & High \\
\hline Micrococcus luteus & High & High & High & High & High \\
\hline Kocuria rosea & High & High & High & High & High \\
\hline Moraxella species & No & High & Low & High & Low \\
\hline Providencia rettgeri & No & High & Low & High & Low \\
\hline
\end{tabular}

High: No bacterial growth. Low: Limited growth, No: no effect

According to Toth (1992) suggests that the counting of human normal flora bacteria above $200 \mathrm{CFU} \mathrm{m}^{-3}$ air be considered high. Hood

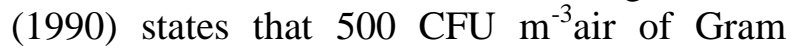
negative bacteria is sufficient to suspect of problems in the indoor air quality. For hospital environments, the maximum number of bacteria CFU allowed by the World Health Organization (WHO) (1988) is $100 \mathrm{CFU} \mathrm{m}^{-3}$ air. In the indoor air samples, the values do not surpass $100 \mathrm{CFU}$. Up to now in Libya there have been no standard regulations concerning permitted levels of microbiological contaminants in indoor air.The study showed that the number of microorganisms was higher in morning during the occupation by staff. A correlation between bacteria and number of persons in a room has been previously suggested by Nevalainen et al., (1992). The most contaminated sites were rooms during work and the corridors .

Current study showed gram positive bacteria high susceptible than gram negative bacteria to all disinfectants used in this study. Sodium hypochlorite (Clorox \& bleach) were the most potent and effective disinfectants against all bacteria tested. These results were comparable to results Guimarães et al., (2000), he showed all strains tested were susceptible to sodium hypochlorite also Bouzada et al., (2010) found Sodium hypochlorite was the compound which showed the highest inhibition concentrations.

According to this study Quaternary ammonium compounds (Biguanid Fläche $\mathrm{N}$ ) and Wipol exhibited high susceptible to gram positive bacteria and lower activity against Gram negative bacteria this was in agreement with Guimarães et al., (2000), he found the susceptible of strains to Quaternary ammonium compounds was variable .Gram-negative bacteria are generally less susceptible to biocides because of their complex cell wall in which the outer membrane of Gram-bacteria act as selective permeability barrier in limiting or prevention the entry of many harmful chemical compounds into the bacterial cell (Saleh, et al., 2012). The present study showed effect Ethanol on Gram positive bacteria and non- activity on Gram negative bacteria. Alkolaible et al., (2015) showed non-significant activity to Ethanol against bacteria tested.

In Conclusion, inside medical lab, indoor air samples showed contamination bacteria under the acceptable levels, when compared with much health organization standardization, also less diversity during afternoon and evening than during morning. Among the bacterial isolate, Micrococcus luteus was reported to be the most prevalent bacterial isolate followed by Staphylococcus capitis sub capitis, Kocuria 
rosea and Acinetobacterlwoffii/haemolyticus. Micrococcus luteus were found in three times in two seasons, while gram negative bacteria only in spring season. The study showed that the number of bacteria was higher in morning during the occupation by staff. In our study, we found that Gram positive bacteria were strongly susceptible to all disinfectants that used in this study. No growth showed in all concentrations of disinfectants. While disinfectants had different effects against Gram negative bacteria.

\section{References}

Alkolaibe, A.M., AL-Ameri G.A, Alkadasi, M.N. and Zaid, A.A. 2015.Study of the Efficacy of Disinfectant against Bacterial Contamination in Burns Unit Algumhory and International Yemen Hospitals in Taiz City. International Journal of Research Studies in Biosciences. 3(Issue 3):26-33.

Bartlett, K.H., Kennedy, S.M, Brauer, M., van Netten, C.and Dill, B. 2004.Evaluation and a predictive model of airborne fungal concentrations in school classrooms. Annals of Occupational Hygiene. 48 (6): 547-554.

Bhatia, L. and Vishwakarma, R.2010. Hospital Indoor Airborne Microflora in Private and Government Owned Hospitals in Sagar City, India. World J Med Sci. 5(3): 65-70.

Bouzada, M.L.M, Silva, V.L., Sa Moreira1, F.A, Silva, G.A. and Diniz, C.G.2010. Antimicrobial resistance and disinfectants susceptibility of persistent bacteria in a tertiary care Hospital. Journal of Microbiology and Antimicrobials. 2(8): 105-112.

British society for antimicrobial chemotherapy (BSAC). 2011. BSAC Methods for Antimicrobial Susceptibility Testing. Version 10.2.

Codina, R., Fox, R.W., Lockey, R.F., DeMarco, P. and Bagg, A. 2008. Typical Levels of Airborne Fungal Spores in Houses without Obvious Moisture Problems during a Rainy Season in Florida, USA.J
Investig Allergol Clin Immunol. 18(3): 156-162.

Ekhaise, F.E. and Ogboghodo, B.I.2011.Microbiological Indoor and Outdoor Air Quality of Two Major Hospitals in Benin City, Nigeria. Sierra Leone J. Biomed. Res. 3(3): 169-174.

Ekhaise, F.O., Isitor, E.E., Idehen, O. and Emoghene, A.O.2010. Airborne Microflora in the Atmosphere of an Hospital Environment of University of Benin Teaching Hospital (UBTH), Benin City, Nigeria. World Journal of Agricultural Sciences. 6 (2): 166-170.

Guimarães, M.A., Tibana, A., Nunes, M.P. and dos Santos, K.R.N.2000. Disinfectant and antibiotic activities: a comparative analysis in Brazilian hospital bacterial isolates. Brazilian Journal of Microbiology. 31:193-199.

Hood, M. A. 1990. Gram-negative bacteria as aerosols. In: Morey, P. R.; Feeley, J. C. and Otten, J. A. (Eds.). Biological Contaminants in Indoor Environments. American Society for Testing and Materials. Philadelphia, Pennsylvania, USA.

Jaffal, A. A., Nsanze, H., Bener, A., Ameen, A.S., Banat, I.M. and El Mogheth, A.A.1997.Hospital airborne microbial pollution in a desert country. Environ. Internat. 23:167-172.

Kelkar, U. and Kulkarni, S. 2011. Contaminated air conditioners as potential source for contaminating operation theatre environment. International Journal of Infection Control. 8(issue 1): 45 - 48.

Kramer, A., Schwebke, I. and Kampf, G. 2006. How long do nosocomial pathogens persist on inanimate surfaces? A systematic review. BMC Infectious Diseases.6:130.

Lee, J.H. and Jo, W.K.2006.Characteristics of indoor and outdoor bioaerosols at Korean highrise apartment buildings. Environmental Research. 101 (1):11-17.

Lehtonen, M., Reponen, T. and Nevalainen, A. 1993.Everyday activities and variation of fungal spore concentrations in indoor air. 
International Biodeterioration Biodegradation. 31: 25-39.

Leung, M. and Chan, A.H.S.2006. Control and management of hospital indoor air quality. Med SciMonit. 12(3): 17-23.

Mahbob, N.S., Kamaruzzaman, S.N., Salleh, N. and Sulaiman, R. 2011.A Correlation Studies of Indoor Environmental Quality (IEQ) Towards Productive Workplace. 2nd International Conference on Environmental Science and Technology. IPCBEE vol.6 (2011) (C) (2011) IACSIT Press, Singapore.

Mandal, J. and Brandl, H. 2011. Bioaerosols in Indoor Environment - A Review with Special Reference to Residential and Occupational Locations. The Open Environmental \& Biological Monitoring Journal. 4: 83-96.

Nevalainen, A., Pastuszka, J., Liebhaber, F. and Willeke, K.1992. Performance of bioaerosol samplers: collection characteristics and sampler design considerations. Atmos. Environ. 26A (4):531-540.

Reijula, K. and Sundman-Digert, C. 2004.Assessment of indoor air problems at work with a questionnaire. Occup Environ Med. 61:33-38.

Saleh, R.H., Naher, H.S. and Al-Jubory, S.A. 2012.A Study of Efficacy of Disinfectants and Bacterial Contamination in AL-Hilla Teaching Hospital. Medical Journal of Babylon. 9(4): 890-900.

Shelton, B.G., Kirkland, K.H., Flanders, W.D. and Morris, G. K. 2002.Profiles of
Airborne Fungi in Buildings and Outdoor Environments in the United States. Applied and environmental microbiology. 68(4): 1743-1753.

Singh, K., Sharma, R., Gupta, P.K., Rana, J.K., Sharma, M. and Taneja, N. 2012. Comparative efficacy evaluation of disinfectants routinely used in hospital practice: India. Indian Journal of Critical Care Medicine. 16 (Issue 3):123-129.

Spendlove, J.C. and Fannin, K.F. 1983. Source, significance, and control of indoor microbial aerosols: Human health aspects. Public Health. 98: 229-244.

Stryjakowska-Sekulska, $\quad$ M. 2007. Microbiological Quality of Indoor Air in University Rooms. Polish J. of Environ. Stud. 16(4): 623-632.

Tada, D.G., Patil, S.R., Tada, G.N. and Patil, S.P.2011. Checking of potency of disinfectant at district level small microbiology laboratory with an example: make own laboratory standard. Int J Biol Med Res. 2(4): 969 -971.

Tambeker, D.H., Gulhane, P.B. and Bhakare, D.D. 2007.Studies on environmental monitoring of microbial air flora in hospitals. J. Med. Sci. 7(1): 67-72.

Toth, C. 1992. Microbial in the overall context of indoor air quality investigation. Proceedings of the Annual IAQ, Conference and Exposition. pp. 255-259.

World Health Organization. 1988. Indoor air quality: biological contaminants. World Health Organization, European Series, n. 31, Copenhagen, Denmark.

\section{How to cite this article:}

Muna Mohammed Buzayan and Bouthina K. Greiw. 2018. Effects of Seasonal Changes in Internal Air Quality and Comparing the Efficacy of Different Disinfectants Used in Laboratory of Benghazi Center of Infectious Diseases and Immunity. Int.J.Curr.Microbiol.App.Sci. 7(06): 340-347. doi: https://doi.org/10.20546/ijcmas.2018.706.038 